\title{
Adult pancreatoblastoma: A case report and review of the literature
}

\author{
EFSTRATIOS ZOUROS $^{1}$, DIMITRIOS K. MANATAKIS ${ }^{1}$, SPIROS G. DELIS ${ }^{1}$, CHRISTOS AGALIANOS ${ }^{1}$, \\ CHARINA TRIANTOPOULOU ${ }^{2}$ and CHRISTOS DERVENIS ${ }^{1}$
}

\author{
Departments of ${ }^{1}$ Surgery and ${ }^{2}$ Radiology, Konstantopouleio General Hospital, Nea Ionia, Athens 14233 , Greece
}

Received December 23, 2014; Accepted January 22, 2015

DOI: 10.3892/ol.2015.3001

\begin{abstract}
The present study describes the case of a 24-year-old patient who presented with obstructive jaundice and weight loss, and was diagnosed with pancreatoblastoma (PB). Abdominal imaging studies revealed a heterogenous lesion of the pancreatic head with dilatation of the common bile duct. The patient underwent pancreaticoduodenectomy, however, three months after surgery multiple liver and bone metastases were identified on follow-up computed tomography scans. Despite treatment with four cycles of systemic chemotherapy and five courses of radiofrequency ablation, the patient succumbed due to tumour dissemination 13 months after initial diagnosis. PB is a malignant tumour of the pancreas that typically occurs in the pediatric population. The aim of the present study was to highlight the aggressive behavior of this rare clinical entity, focusing on the pitfalls of pre-operative diagnosis and the lack of management strategy guidelines in adults. Preoperative diagnosis of PB based on radiographic features may be difficult, as the imaging characteristics are non-specific. Furthermore, cytology may also be misleading, as the neoplasm consists of multiple cell lines (acinar, ductal and neuroendocrine cells) and diagnosis depends largely on the identification of the distinctive histological characteristic of squamoid corpuscles, which present as nests of flattened cells with a squamous appearance. Despite the use of surgical resection and adjuvant chemoradiotherapy for the treatment of this malignancy, its aggressive nature means that $\mathrm{PB}$ is associated with a poor prognosis in adult patients.
\end{abstract}

Correspondence to: Mr. Dimitrios K. Manatakis, Department of Surgery, Konstantopouleio General Hospital, 3-5 Agias Olgas, Nea Ionia, Athens 14233, Greece

E-mail:dmanatak@yahoo.gr

Abbreviations: PB, pancreatoblastoma; AFP, $\alpha$-fetoprotein; CEA, carcinoembryonic antigen

Key words: pancreatoblastoma, pancreatic neoplasms, adult, pancreas

\section{Introduction}

Pancreatoblastoma (PB) is a rare epithelial neoplasm of the pancreas, typically occurring in the pediatric population. Since the first report of PB in 1957, >200 cases have been described in children, yet only 39 cases have been described in adult patients $(1,2)$.

$\mathrm{PB}$ is an aggressive and malignant tumour, exhibiting high rates of local invasion, recurrence and distant metastatic potential. Furthermore, adult patients with PB have a poor prognosis compared with pediatric patients (3). Symptoms are usually vague and radiological features are non-specific. Thus, diagnosis depends largely on the identification of characteristic squamoid corpuscles on histopathological examination, which would appear as whorled nests of flattened cells with a squamous appearance.

Due to its rarity, no guidelines currently exist on the management protocols for PB. Surgery is considered to be the chief treatment strategy, while the role of chemoradiotherapy remains unclear and the significant benefits of the currently employed regimens are limited (3).

The current study presents the case of a 24-year-old patient who was diagnosed with a rare pathology of $\mathrm{PB}$, but succumbed one year later due to disseminated metastatic disease. In addition, a brief review of the relevant literature is discussed. Written informed consent was obtained from the patient's family.

\section{Case report}

In March 2013, a 24-year-old Caucasian, male patient was admitted to the Department of Surgery, Konstantopouleio General Hospital (Athens, Greece) with a three-week history of vague upper abdominal discomfort, anorexia and weight loss. A physical examination revealed obstructive jaundice and mild tenderness over the epigastrium.

Laboratory tests identified elevated serum levels of aspartate aminotransferase (247 IU/1; normal range, 10-37 IU/1), alanine aminotransferase (289 IU/1; normal range, 12-78 IU/1), alkaline phosphatase (563 IU/1; normal range, 46-116 IU/1), $\gamma$-glutamyl transpeptidase (703 IU/1; normal range, $15-85 \mathrm{IU} / \mathrm{l})$, direct bilirubin $(15.9 \mathrm{mg} / \mathrm{dl}$; normal range, $<0.3 \mathrm{mg} / \mathrm{dl})$ and total bilirubin $(17 \mathrm{mg} / \mathrm{dl}$; normal range, $<1 \mathrm{mg} / \mathrm{dl}$ ). However, carcinoembryonic antigen (CEA), 


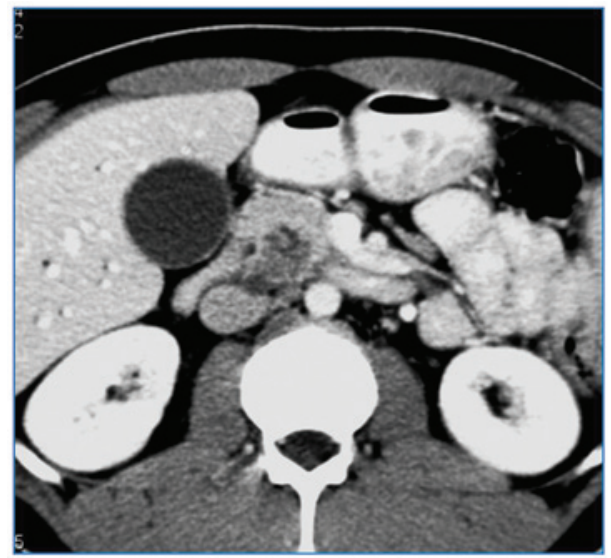

Figure 1. Contrast enhanced computed tomography image demonstrating a heterogeneous hypodense mass in the posterior aspect of the pancreatic head. No dilatation of the main pancreatic duct or involvement of either vessel is indicated.

$\alpha$-fetoprotein (AFP) and cancer antigen (CA)19-9 levels were within the normal ranges.

An abdominal ultrasound demonstrated the presence of an encapsulated and well-defined mass in the head of the pancreas. Contrast-enhanced computed tomography (CT) scans confirmed a heterogeneous, hypodense mass in the pancreatic head, with no dilatation of the main pancreatic duct and no vascular involvement (Fig. 1). Furthermore, contrast-enhanced magnetic resonance imaging indicated the presence of a hypoenhancing, low-intensity mass in the posterior aspect of the pancreatic head abutting the distal section of the common bile duct on T1-weighted images (Fig. 2). A high signal intensity was observed on T2-weighted images (Fig. 3). In addition, magnetic resonance cholangiopancreatography revealed obliteration of the distal common bile duct, with marked proximal dilatation (Fig. 4).

The patient underwent an exploratory laparotomy, during which a palpable mass measuring $\sim 8 \times 7 \times 8 \mathrm{~cm}$ was identified in the pancreatic head. No vascular invasion or distant metastases were observed, therefore, a pylorus-preserving pancreaticoduodenectomy was performed. The post-operative course was uneventful and the patient was discharged on the seventh post-operative day.

Histopathological analysis of the resected lesion demonstrated typical features of PB. The tumour was composed of a combination of undifferentiated small cells, and epithelial and stromal components with partial encapsulation. The epithelial component was dominant and demonstrated an acinar architecture, solid sheets and squamoid corpuscles.

Follow-up abdominal CT scans were performed three months post-operatively, and revealed multiple liver and bone metastases. The patient underwent five courses of radiofrequency ablation (15-minute courses of $60 \mathrm{~W}$ thermoablation with Elektrotom 106 HiTT needle, Berchtold GmbH and Co. KG, Tuttlingen, Germany) combined with four cycles of systemic chemotherapy, consisting of cisplatin $\left(80 \mathrm{mg} / \mathrm{m}^{2}\right.$ over $24 \mathrm{~h}$ ) and doxorubicin (60 mg/m $\mathrm{m}^{2}$ over $48 \mathrm{~h}$ ), each course lasted three weeks; however, no response was observed and the patient succumbed 13 months after initial diagnosis due to tumour dissemination.

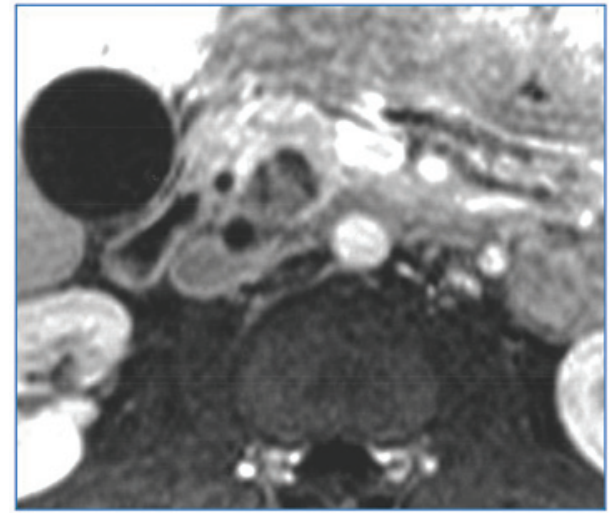

Figure 2. Contrast enhanced T1-weighted magnetic resonance image demonstrating a hypoenhancing low-intensity mass in the posterior aspect of the pancreatic head, abutting the distal part of the common bile duct.

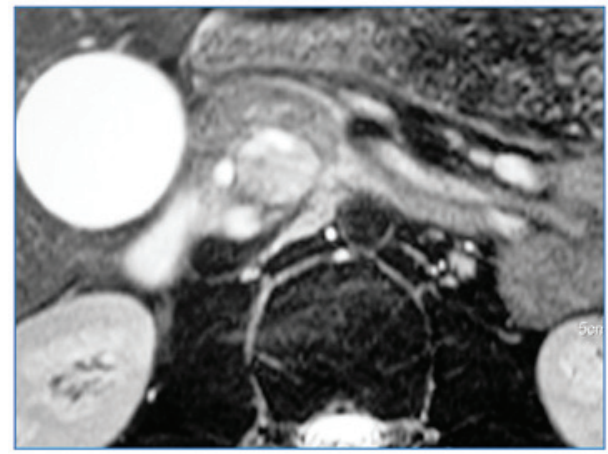

Figure 3. T2-weighted magnetic resonance image. The lesion appears sharply marginated with a heterogenous high-intensity signal.

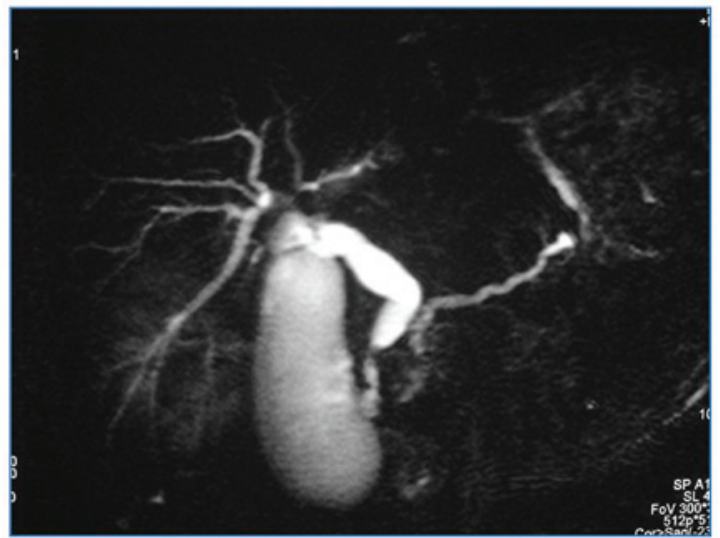

Figure 4. Magnetic resonance cholangiopancreatography indicating obliteration of the distal common bile duct with marked upstream dilatation and mild infiltration of the main pancreatic duct in the pancreatic head. The gallbladder is also dilated.

\section{Discussion}

Adult PB is a rare neoplasm of epithelial origin, accounting for $<0.5 \%$ of exocrine pancreatic tumours (3). PB was initially described by Becker (1) in 1957 as infantile pancreatic carcinoma, however, Horie et al (4) coined the term pancreatoblastoma in 1977. To date, since Palosaari et al (5) 
Table I. Adult pancreatoblastoma cases in the literature (1986-2014).

\begin{tabular}{|c|c|c|c|c|c|c|}
\hline First author/s (ref.) & Year & Age $^{\mathrm{a}} /$ gender & Symptoms & Tumour details & Treatment strategy & Follow-up \\
\hline Palosaari et al (5) & 1986 & $37 / \mathrm{M}$ & $\begin{array}{l}\text { Abdominal pain, } \\
\text { weight loss, } \\
\text { diarrhea }\end{array}$ & $\begin{array}{l}8 \mathrm{~cm} \text {, head, } \\
\mathrm{LN} \text { and vascular } \\
\text { involvement }\end{array}$ & $\begin{array}{l}\text { Incomplete } \\
\text { resection, } \\
\text { chemoradiotherapy }\end{array}$ & $\begin{array}{l}\text { With liver } \\
\text { metastases at } \\
15 \text { months }\end{array}$ \\
\hline Hoorens et al (6) & 1994 & $39 / \mathrm{F}$ & Abdominal mass & $13 \mathrm{~cm}$, tail & Resection & $\begin{array}{l}\text { NED at } \\
30 \text { months }\end{array}$ \\
\hline $\begin{array}{l}\text { Dunn and } \\
\text { Longnecker ( } 7)\end{array}$ & 1995 & $61 / \mathrm{M}$ & Splenomegaly & $9 \mathrm{~cm}$, tail & $\begin{array}{l}\text { Resection, } \\
\text { chemotherapy }\end{array}$ & $\begin{array}{l}\text { Succumbed } \\
\text { after } 11 \text { months }\end{array}$ \\
\hline \multirow[t]{5}{*}{ Klimstra et al (8) } & 1995 & $19 / \mathrm{M}$ & Abdominal mass & $\begin{array}{l}15 \mathrm{~cm} \text {, head; } \\
\text { LN involvement, } \\
\text { multiple metastases }\end{array}$ & Resection & $\begin{array}{l}\text { Succumbed } \\
\text { after } 10 \text { months }\end{array}$ \\
\hline & & $36 / \mathrm{M}$ & $\begin{array}{l}\text { Obstructive } \\
\text { jaundice, }\end{array}$ & $\begin{array}{l}\text { 'Large', head, } \\
\text { LN involvement, } \\
\text { liver metastasis }\end{array}$ & None & $\begin{array}{l}\text { Succumbed } \\
\text { after } 5 \text { months }\end{array}$ \\
\hline & & $37 / \mathrm{M}$ & $\begin{array}{l}\text { Abdominal mass, } \\
\text { weight loss }\end{array}$ & $\begin{array}{l}12 \mathrm{~cm}, \text { head, } \\
\text { liver metastasis }\end{array}$ & Chemoradiotherapy & $\begin{array}{l}\text { Succumbed } \\
\text { after } 38 \text { months }\end{array}$ \\
\hline & & $54 / \mathrm{F}$ & Abdominal pain & $20 \mathrm{~cm}$, tail & Resection & $\begin{array}{l}\text { NED at } \\
15 \text { months }\end{array}$ \\
\hline & & $56 / \mathrm{M}$ & Abdominal mass & $20 \mathrm{~cm}$, tail & Resection & $\begin{array}{l}\text { NED at } \\
5 \text { months }\end{array}$ \\
\hline $\begin{array}{l}\text { Levey and } \\
\text { Banner (9) }\end{array}$ & 1996 & $68 / \mathrm{F}$ & $\begin{array}{l}\text { Diarrhea, weight } \\
\text { loss }\end{array}$ & $9 \mathrm{~cm}$, head & Resection & $\begin{array}{l}\text { Succumbed } \\
\text { after } 4 \text { months }\end{array}$ \\
\hline Robin et al (10) & 1997 & 20/M & Abdominal mass & $9 \mathrm{~cm}$ head & $\begin{array}{l}\text { Resection, } \\
\text { chemotherapy }\end{array}$ & $\begin{array}{l}\text { Succumbed } \\
\text { after } 7 \text { months }\end{array}$ \\
\hline Hayasaki et al (11) & 1999 & $48 / \mathrm{F}$ & $\begin{array}{l}\text { Urinary occult } \\
\text { blood }\end{array}$ & $5 \mathrm{~cm}$, tail & Resection & $\begin{array}{l}\text { NED at } \\
15 \text { months }\end{array}$ \\
\hline $\begin{array}{l}\text { Montemarano } \\
\text { et al (12) }\end{array}$ & 2000 & $20 / \mathrm{F}$ & $\begin{array}{l}\text { Obstructive } \\
\text { jaundice }\end{array}$ & Head & Resection & No data \\
\hline Mumme et al (13) & 2001 & $22 / \mathrm{F}$ & $\begin{array}{l}\text { Abdominal pain, } \\
\text { mass, weight loss }\end{array}$ & $9 \mathrm{~cm}$, tail & $\begin{array}{l}\text { Resection, } \\
\text { intraoperative } \\
\text { radiotherapy, } \\
\text { chemotherapy }\end{array}$ & $\begin{array}{l}\text { Succumbed } \\
\text { after } 9 \text { months }\end{array}$ \\
\hline Benoist et al (14) & 2001 & $48 / \mathrm{F}$ & $\begin{array}{l}\text { Abdominal pain, } \\
\text { melaena }\end{array}$ & $\begin{array}{l}10 \mathrm{~cm} \text {, body, } \\
\text { liver metastasis }\end{array}$ & $\begin{array}{l}\text { Resection, } \\
\text { metastasectomy, } \\
\text { chemotherapy }\end{array}$ & $\begin{array}{l}\text { NED at } \\
36 \text { months }\end{array}$ \\
\hline Abraham et al (15) & 2001 & $45 / \mathrm{F}$ & No data & No data & No data & No data \\
\hline & 2001 & $51 / \mathrm{F}$ & No data & No data & No data & No data \\
\hline Gruppioni et al (16) & 2002 & $30 / \mathrm{M}$ & Abdominal pain & $8 \mathrm{~cm}$, head & Resection & $\begin{array}{l}\text { NED at } \\
10 \text { months }\end{array}$ \\
\hline Du et al (17) & 2003 & $78 / \mathrm{F}$ & $\begin{array}{l}\text { Obstructive } \\
\text { jaundice }\end{array}$ & $\begin{array}{l}2.7 \mathrm{~cm}, \text { ampulla } \\
\text { of Vater }\end{array}$ & Resection & $\begin{array}{l}\text { NED at } \\
6 \text { months, } \\
\text { alive at } 4 \text { years }\end{array}$ \\
\hline $\begin{array}{l}\text { Pitman and } \\
\text { Faquin (18) }\end{array}$ & 2004 & $18 / \mathrm{M}$ & $\begin{array}{l}\text { Abdominal pain, } \\
\text { weight loss, } \\
\text { diarrhea }\end{array}$ & $\begin{array}{l}9 \mathrm{~cm}, \text { head, } \\
\text { vascular } \\
\text { involvement }\end{array}$ & $\begin{array}{l}\text { Neoadjuvant } \\
\text { chemoradiotherapy, } \\
\text { resection, multiple } \\
\text { metastasectomies }\end{array}$ & $\begin{array}{l}\text { With lung } \\
\text { metastases at } \\
7 \text { years }\end{array}$ \\
\hline Rosebrook et al (19) & 2005 & $29 / \mathrm{F}$ & Abdominal pain & $2 \mathrm{~cm}$, body & Resection & No data \\
\hline Sheng et al (20) & 2005 & $18 / \mathrm{M}$ & $\begin{array}{l}\text { Abdominal pain, } \\
\text { obstructive jaundice }\end{array}$ & $10 \mathrm{~cm}$, body & $\begin{array}{l}\text { Resection, adjuvant } \\
\text { chemoradiotherapy, } \\
\text { liver TAE }\end{array}$ & $\begin{array}{l}\text { Succumbed } \\
\text { after } 26 \text { months }\end{array}$ \\
\hline Zhu et al (21) & 2005 & $24 / \mathrm{F}$ & Obstructive jaundice & $\begin{array}{l}4 \mathrm{~cm}, \text { body, } \\
\text { liver metastases }\end{array}$ & $\begin{array}{l}\text { Chemotherapy, } \\
\text { unresectable }\end{array}$ & $\begin{array}{l}\text { With liver } \\
\text { metastases at } \\
9 \text { months }\end{array}$ \\
\hline
\end{tabular}


Table I. Continued.

\begin{tabular}{|c|c|c|c|c|c|c|}
\hline First author/s (ref.) & Year & Age $^{\mathrm{a}} /$ gender & Symptoms & Tumour details & Treatment strategy & Follow-up \\
\hline Kuxhaus et al (22) & 2005 & $69 / \mathrm{M}$ & Fever, weight loss & $\begin{array}{l}\text { 'Large', tail, } \\
\text { peritoneal } \\
\text { carcinomatosis }\end{array}$ & Unresectable & No data \\
\hline Rajpal et al (23) & 2006 & $50 / \mathrm{M}$ & $\begin{array}{l}\text { Abdominal pain, } \\
\text { weight loss }\end{array}$ & $\begin{array}{l}13 \mathrm{~cm} \text {, tail, colon } \\
\text { invasion, liver } \\
\text { metastasis }\end{array}$ & $\begin{array}{l}\text { Resection, } \\
\text { chemotherapy }\end{array}$ & $\begin{array}{l}\text { Succumbed } \\
\text { after } 17 \text { months }\end{array}$ \\
\hline $\begin{array}{l}\text { Charlton-Ouw } \\
\text { et al }(26)\end{array}$ & 2008 & $33 / \mathrm{M}$ & $\begin{array}{l}\text { Abdominal pain, } \\
\text { mass, weight loss }\end{array}$ & $\begin{array}{l}5 \mathrm{~cm}, \text { head, } \\
\text { liver metastasis }\end{array}$ & $\begin{array}{l}\text { Metastectomy, } \\
\text { resection, } \\
\text { chemoradiotherapy }\end{array}$ & $\begin{array}{l}\text { NED at } \\
60 \text { months }\end{array}$ \\
\hline Ohike et al (27) & 2008 & $74 / \mathrm{F}$ & Asymptomatic & $4.5 \mathrm{~cm}$, head & Excision & $\begin{array}{l}\text { NED at } \\
108 \text { months }\end{array}$ \\
\hline \multirow[t]{2}{*}{ Cavallini et al (24) } & \multirow[t]{2}{*}{2009} & 69/M & Asymptomatic & $6 \mathrm{~cm}$, body & Resection & $\begin{array}{l}\text { NED at } \\
15 \text { months }\end{array}$ \\
\hline & & 26/M & Abdominal pain & $5 \mathrm{~cm}$, head & Resection & $\begin{array}{l}\text { NED at } \\
51 \text { months }\end{array}$ \\
\hline Comper et al (25) & 2009 & $\begin{array}{l}27 / \mathrm{M} \\
69 / \mathrm{M}\end{array}$ & $\begin{array}{l}\text { No data } \\
\text { No data }\end{array}$ & $\begin{array}{l}5.5 \mathrm{~cm}, \text { head } \\
5.5 \mathrm{~cm}, \text { body }\end{array}$ & $\begin{array}{l}\text { Resection } \\
\text { Resection }\end{array}$ & $\begin{array}{l}\text { No data } \\
\text { No data }\end{array}$ \\
\hline Savastano et al (28) & 2009 & $36 / \mathrm{F}$ & Obstructive jaundice & $\begin{array}{l}4.3 \mathrm{~cm}, \text { head, } \\
\text { LN involvement }\end{array}$ & $\begin{array}{l}\text { Resection, adjuvant } \\
\text { chemoradiotherapy }\end{array}$ & No data \\
\hline Boix et al (29) & 2010 & $33 / \mathrm{F}$ & Abdominal pain & $3.5 \mathrm{~cm}$, body & Resection & $\begin{array}{l}\text { Succumbed } \\
\text { after } 3 \text { months }\end{array}$ \\
\hline $\begin{array}{l}\text { Balasundaram } \\
\text { et al }(30)\end{array}$ & 2012 & $27 / F$ & Weight loss & $\begin{array}{l}3.6 \mathrm{~cm}, \text { body, } \\
\text { liver and lung } \\
\text { metastases }\end{array}$ & Chemotherapy & $\begin{array}{l}\text { Succumbed } \\
\text { after } 1 \text { month }\end{array}$ \\
\hline Gringeri et al (31) & 2012 & $38 / \mathrm{F}$ & No data & Head & $\begin{array}{l}\text { Resection, } \\
\text { chemotherapy, } \\
\text { CyberKnife }{ }^{\circledR}, \text { liver } \\
\text { metastasectomies }\end{array}$ & $\begin{array}{l}\text { NED at } \\
44 \text { months }\end{array}$ \\
\hline $\begin{array}{l}\text { Hammer and } \\
\text { Owens (32) }\end{array}$ & 2013 & $37 / \mathrm{M}$ & $\begin{array}{l}\text { Abdominal pain, } \\
\text { obstructive jaundice }\end{array}$ & $7 \mathrm{~cm}$, head & Resection & No data \\
\hline Redelman et al (33) & 2013 & $26 / \mathrm{F}$ & No data & $7.5 \mathrm{~cm}$, head & Resection & No data \\
\hline \multirow[t]{3}{*}{ Salman et al (3) } & \multirow[t]{3}{*}{2013} & $60 / \mathrm{M}$ & Abdominal pain & $\begin{array}{l}1.8 \mathrm{~cm}, \text { head, } \\
\text { liver metastasis }\end{array}$ & $\begin{array}{l}\text { Resection, } \\
\text { chemotherapy }\end{array}$ & $\begin{array}{l}\text { NED at } \\
41 \text { months }\end{array}$ \\
\hline & & $51 / \mathrm{M}$ & $\begin{array}{l}\text { Obstructive } \\
\text { jaundice, weight } \\
\text { loss }\end{array}$ & $\begin{array}{l}4 \mathrm{~cm}, \text { head, } \\
\text { duodenum } \\
\text { invasion, LN } \\
\text { involvement }\end{array}$ & $\begin{array}{l}\text { Chemotherapy, } \\
\text { resection }\end{array}$ & $\begin{array}{l}\text { Succumbed } \\
\text { after } 51 \text { months }\end{array}$ \\
\hline & & $58 / \mathrm{F}$ & Abdominal pain & $\begin{array}{l}4.5 \mathrm{~cm}, \text { tail, } \\
\mathrm{LN} \text { involvement }\end{array}$ & Resection & $\begin{array}{l}\text { NED at } \\
30 \text { months }\end{array}$ \\
\hline Present case & 2015 & 24/M & $\begin{array}{l}\text { Abdominal pain, } \\
\text { weight loss, } \\
\text { obstructive jaundice }\end{array}$ & $8 \mathrm{~cm}$, head & $\begin{array}{l}\text { Resection, } \\
\text { chemotherapy }\end{array}$ & $\begin{array}{l}\text { Succumbed } \\
\text { after } 13 \text { months }\end{array}$ \\
\hline
\end{tabular}

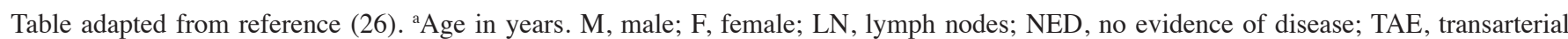
embolisation.

reported the first case of $\mathrm{PB}$ in a 37 -year-old patient in 1986 , only 39 cases have been published in the literature (Table I) (3,5-33). A literature search of PubMed was conducted with no language restrictions; studies published between 1986 and 2014 were searched using the key words 'pancreatoblastoma', 'pancreas', 'pancreatic tumour' and 'pancreatic neoplasm'. Additional studies were identified from the references of the retrieved papers. Cases of PB affecting patients $\geq 18$ years of age were included in the analysis. 
PB displays a bimodal age distribution (modal ages, 2.5 and 40 years), while both genders are equally affected (male:female ratio, 1:1) $(3,31)$. The majority of cases are sporadic, however, specific cases are associated with hereditary syndromes, such as Beckwith-Wiedeman and familial adenomatous polyposis syndromes (32).

Symptoms are typically vague and non-specific $(3,17,24,30)$. For example, the majority of adult patients present with abdominal pain or a palpable mass. Additionally, weight loss, anorexia and a change in bowel habits are common symptoms on initial presentation. PBs arising in the pancreatic head may cause biliary obstruction and jaundice, as in the present case. Furthermore, patients may manifest symptoms of endocrine abnormalities (15).

In the present literature review, the pancreatic head, observed in $20 / 38$ patients $(53 \%)$ was the most common site of tumour origin, followed by the tail, the body and the ampulla of Vater (no tumour site data for two patients). The liver has been found to be the most common site of distant metastasis and $25 \%$ of cases are diagnosed with secondary liver disease upon initial staging $(19,24,30)$. However, bone, pulmonary, peritoneal, brain and mediastinal metastases have also been described $(19,26)$.

In paediatric PB patients, elevated AFP and CEA levels are the most common abnormal serological markers, and elevated AFP expression has been reported in $\leq 68 \%$ of cases $(12,24,25,32)$, By contrast, these PB tumour markers are typically within the normal range in adult patients $(1,3)$. Serum AFP levels may be used to monitor clinical response to therapy or recurrence in those patients whose tumors produce it (32).

Forming an accurate pre-operative diagnosis may be difficult when based solely on radiographic features, as these are non-specific and thus, PB cases may be mistaken for more common entities, such as adenocarcinoma or neuroendocrine tumours. The majority of PB tumours are well-defined, large and heterogeneous on cross-sectional imaging, with mixed solid-cystic appearance $(3,19,24,26,30)$. On magnetic resonance, the tumours are most commonly described as heterogeneous with low-intermediate T1 signal intensity and high T2 intensity. Furthermore, PB tumours exhibit enhancement on contrast-enhanced CT scans, with calcifications and internal fibrous septa observed $(3,24,30)$.

The differential diagnosis for PB includes benign and malignant processes of the pancreas, including autoimmune pancreatitis, adenocarcinoma, neuroendocrine tumours, solid pseudopapillary tumours, mucinous cystic neoplasms and serous microcystic adenoma $(3,32)$.

Macroscopically, PB lesions are typically large $(\leq 20 \mathrm{~cm}$ in diameter), partially-encapsulated, greyish or tan in colour, with a soft consistency and areas of focal necrosis (3). Microscopic diagnosis may be difficult due to histological heterogeneity. PB tumours often contain multiple cell types, and demonstrate variable combinations of ductal, acinar and neuroendocrine components. This variety of elements is one of the distinctive pathological features of $\mathrm{PB}$, the other being the presence of squamoid corpuscles (i.e., circumscribed, whorled nests of flattened cells with a squamous appearance, separated by dense stromal bands) $(3,32)$.

Ductal adenocarcinoma, acinar cell carcinoma, neuroendocrine neoplasms and solid pseudopapillary tumours all lack the characteristic squamoid corpuscles observed in PB. Therefore, pre-operative cytology is rarely useful, as accurate pre-operative identification of squamoid corpuscles cannot be performed due to sampling errors $(3,18,21,33,34)$. However, PB does not demonstrate the desmoplastic reaction that occurs in adenocarcinoma, allowing differentiation from PB (32).

Immunohistochemistry may facilitate the characterisation of various components of the tumour. For example, acinar cell lines stain positive for trypsin, chymotrypsin and lipase, whereas neuroendocrine cells stain positive for synaptophysin, chromogranin and neuron-specific enolase $(3,32)$. In addition, immunohistochemical analysis of AFP expression may be positive within solid regions of the epithelial component.

Unlike pancreatic ductal adenocarcinoma, PB does not appear to express the K-ras oncogene or p53 tumour suppressor mutations $(15,26)$. However, mutations of the adenomatous polyposis coli/ $\beta$-catenin pathway have been described, and allelic loss on chromosome 11p (Wnt signaling pathway) is the most common type of genetic alteration that has been identified in PB $(12,15,26,35,36)$. Furthermore, numerous paediatric cases of $\mathrm{PB}$ have occurred in patients with Beckwith-Wiedemann syndrome and familial adenomatous polyposis $(12,15,19,26,32)$.

Due to the rarity of $\mathrm{PB}$, an optimal treatment strategy has yet to be standardised, however, in the adult population, surgical resection remains the primary treatment strategy $(3,24)$. The roles of adjuvant chemotherapy and radiotherapy remain under debate due to the small number of patients treated thus far. Typically, chemotherapy with or without radiotherapy has a role in the treatment of recurrent, residual, unresectable and metastatic disease, although with variable outcomes $(3,24)$. However, the development of optimal chemotherapeutic regimens remain under discussion due to the small number of patients reported in the literature (26). In patients with incompletely resected disease, post-operative radiotherapy may be administered as a palliative treatment (3).

PBs exhibit malignant behaviour, with local invasion, recurrence and distant metastasis, and adult $\mathrm{PB}$ patients have a poorer prognosis compared with children, exhibiting three-year survival rates of $<40 \%(3,12,19,24)$. Patients with unresected tumours have a median overall survival time of five months, whereas surgery alone is associated with an overall survival time of 15 months. Furthermore, treatment with chemoradiotherapy following surgery appears to increase the overall survival time to 20.5 months (3). The limited number of reported cases does not allow for valid conclusions to be drawn, however, positive lymph node involvement has been associated with a poorer outcome (overall survival of 12 vs. 36 months with negative node involvement) (3). In addition, there is insufficient data available to evaluate survival with or without vascular or perineural invasion (3).

Although the benefits of neoadjuvant chemotherapy have yet to be studied in randomised trials, it has demonstrated a survival benefit in a small pediatric series (37). Of six pediatric patients treated with neoadjuvant chemotherapy, five exhibited $>50 \%$ tumour remission, allowing for complete surgical resection in four of the five patients, the fifth patient underwent a laparotomy, however the tumour remained unresectable due to regional extension, and one patient achieved complete tumour regression (37). Therefore, neoadjuvant chemotherapy may have 
a role in the treatment of adult $\mathrm{PB}$, predominantly in identifying patients with responsive disease, who may be candidates for surgical resection.

In conclusion, $\mathrm{PB}$ is an extremely rare neoplasm in adults and the present study showcases its aggressive biological and clinical behaviour. The patient presented with a three-week history of obstructive jaundice and weight loss, and was diagnosed with a pancreatic head mass. Following pancreaticoduodenectomy, the patient developed multiple liver and bone metastases three months later, and despite systemic chemotherapy and radiofrequency ablation, succumbed to tumour dissemination. Pitfalls in the pre-surgical diagnosis of $\mathrm{PB}$, based currently on radiological and cytological findings, and lack of management guidelines, due to the paucity of the tumour, result in a generally unfavourable patient prognosis.

\section{References}

1. Becker WF: Pancreatoduodenectomy for carcinoma of the pancreas in an infant; report of a case. Ann Surg 145: 864-870; discussion, 870-872, 1957.

2. Argon A, Celik A, Onız H, Ozok G and Barbet FY: Pancreatoblastoma, a rare childhood tumor: A case report. Turk Patoloji Derg 11: 1-5, 2014.

3. Salman B, Brat G, Yoon YS, et al: The diagnosis and surgical treatment of pancreatoblastoma in adults: a case series and review of the literature. J Gastrointest Surg 17: 2153-2161, 2013.

4. Horie A, Yano Y, Kotoo Y and Miwa A: Morphogenesis of pancreatoblastoma, infantile carcinoma of the pancreas: report of two cases. Cancer 39: 247-254, 1977.

5. Palosaari D, Clayton F and Seaman J: Pancreatoblastoma in an adult. Arch Pathol Lab Med 110: 650-652, 1986.

6. Hoorens A, Gebhard F, Kraft K, Lemoine NR and Klöppel G: Pancreatoblastoma in an adult: its separation from acinar cell carcinoma. Virchows Arch 424: 485-490, 1994.

7. Dunn JL and Longnecker DS: Pancreatoblastoma in an older adult. Arch Pathol Lab Med 119: 547-551, 1995.

8. Klimstra DS, Wenig BM, Adair CF and Heffess CS: Pancreatoblastoma. A clinicopathologic study and review of the literature. Am J Surg Pathol 19: 1371-1389, 1995.

9. Levey JM and Banner BF: Adult pancreatoblastoma: a case report and review of the literature. Am J Gastroenterol 91: 1841-1844, 1996.

10. Robin E, Terris B, Valverde A, Molas G, Belghiti J, Bernades P and Ruszniewski P: Pancreatoblastoma in adults. Gastroenterol Clin Biol 21: 880-883, 1997 (In French).

11. Hayasaki N, Miyake N, Takahashi H, Nakamura E, Yamagishi S, Kuno Y, Mori N, Shinoda M, Kimura M, Suzuki T and Tashiro K: A case of pancreatoblastoma in an adult. Nihon Shokakibyo Gakkai Zasshi 96: 558-563, 1999 (In Japanese).

12. Montemarano H, Lonergan GJ, Bulas DI and Selby DM: Pancreatoblastoma : imaging findings in 10 patients and review of the literature. Radiology 214: 476-482, 2000.

13. Mumme T, Büttner R, Peiper C and Schumpelick V: Pancreatoblastoma: a rare malignant neoplasm in early adulthood. Chirurg 72: 806-811, 2001 (In German).

14. Benoist S, Penna C, Julié C, Malafosse R, Rougier P and Nordlinger B: Prolonged survival after resection of pancreatoblastoma and synchronous liver metastases in an adult Hepatogastroenterology 48: 1340-1342, 2001.

15. Abraham SC, Wu TT, Klimstra DS, Finn LS, Lee JH, Yeo CJ, Cameron JL and Hruban RH: Distinctive molecular genetic alterations in sporadic and familial adenomatous polyposis-associated pancreatoblastomas: frequent alterations in the APC/beta-catenin pathway and chromosome 11p. Am J Pathol 159: 1619-1627, 2001.

16. Gruppioni F, Casadei R, Fusco F, Calculli L, Marrano D and Gavelli G: Adult pancreatoblastoma. A case report. Radiol Med 103: 119-122, 2002.
17. Du E, Katz M, Weidner N, Yoder S, Moossa AR and Shabaik A: Ampullary pancreatoblastoma in an elderly patient: a case report and review of the literature. Arch Pathol Lab Med 127: 1501-1505, 2003.

18. Pitman MB and Faquin WC: The fine-needle aspiration biopsy cytology of pancreatoblastoma. Diagn Cytopathol 31: 402-406, 2004.

19. Rosebrook JL, Glickman JN and Mortele KJ: Pancreatoblastoma in an adult woman: sonography, CT, and dynamic gadolinium-enhanced MRI features. AJR Am J Roentgenol 184 (Suppl): S78-S81, 2005.

20. Sheng L, Weixia Z, Longhai Y and Jinming Y: Clinical and biologic analysis of pancreatoblastoma. Pancreas 30: 87-90, 2005.

21. Zhu LC, Sidhu GS, Cassai ND and Yang GC: Fine-needle aspiration cytology of pancreatoblastoma in a young woman: report of a case and review of the literature. Diagn Cytopathol 33: $258-262,2005$

22. Kuxhaus L, Swayne LC, Chevinsky A and Samli B: Adult metastatic pancreaticoblastoma detected with Tc-99m MDP bone scan. Clin Nucl Med 30: 577-578, 2005.

23. Rajpal S, Warren RS, Alexander M, et al: Pancreatoblastoma in an adult: case report and review of the literature. J Gastrointest Surg 10: 829-836, 2006.

24. Cavallini A, Falconi M, Bortesi L, Crippa S, Barugola G and Butturini G: Pancreatoblastoma in adults: a review of the literature. Pancreatology 9: 73-80, 2009.

25. Comper F, Antonello D, Beghelli S, Gobbo S, Montagna L, Pederzoli P, Chilosi M and Scarpa A: Expression pattern of claudins 5 and 7 distinguishes solid-pseudopapillary from pancreatoblastoma, acinar cell and endocrine tumors of the pancreas. Am J Surg Pathol 33: 768-774, 2009.

26. Charlton-Ouw KM, Kaiser CL, Tong GX, Allendorf JD and Chabot JA: Revisiting metastatic adult pancreatoblastoma. A case and review of the literature. JOP 9: 733-738, 2008.

27. Ohike N, Yamochi T, Shiokawa A, Yoshida T, Yamazaki T, Date Y and Morohoshi T: A peculiar variant of pancreatoblastoma in an adult. Pancreas 36: 320-322, 2008.

28. Savastano S, d'Amore ES,Zuccarotto D, et al: Pancreatoblastoma in an adult patient. A case report. JOP 10: 192-195, 2009.

29. Boix E, Yuste A, Meana A, Alcaraz E, Payá A, Arnold C, Picó A and Lluis F: Corticotrophin-releasing hormone-secreting pancreatoblastoma in an adult patient. Pancreas 39: 938-939, 2010.

30. Balasundaram C, Luthra M, Chavalitdhamrong D, Chow J, Khan $\mathrm{H}$ and Endres PJ: Pancreatoblastoma: A rare tumor still evolving in clinical presentation and histology. JOP 13: 301-303, 2012 .

31. Gringeri E, Polacco M, D'Amico FE, et al: Liver autotransplantation for the treatment of unresectable hepatic metastasis: an uncommon indication - a case report. Transplant Proc 44: 1930-1933, 2012.

32. Hammer ST and Owens SR: Pancreatoblastoma: a rare, adult pancreatic tumor with many faces. Arch Pathol Lab Med 137: 1224-1226, 2013.

33. Redelman M, Cramer HM and Wu HH: Pancreatic fine-needle aspiration cytology in patients $<35$-years of age: a retrospective review of 174 cases spanning a 17 -year period. Diagn Cytopathol 42: 297-301, 2014.

34. Sigel CS and Klimstra DS: Cytomorphologic and immunophenotypical features of acinar cell neoplasms of the pancreas. Cancer Cytopathol 121: 459-470, 2013.

35. Jiao Y, Yonescu R, Offerhaus GJ, et al: Whole-exome sequencing of pancreatic neoplasms with acinar differentiation. J Pathol 232: 428-435, 2014.

36. Wood LD and Klimstra DS: Pathology and genetics of pancreatic neoplasms with acinar differentiation. Semin Diagn Pathol 31: 491-497, 2014.

37. Défachelles A, Martin De Lasalle E, Boutard P, Nelken B, Schneider P and Patte C: Pancreatoblastoma in childhood: clinical course and therapeutic management of seven patients. Med Pediatr Oncol 37: 47-52, 2001. 